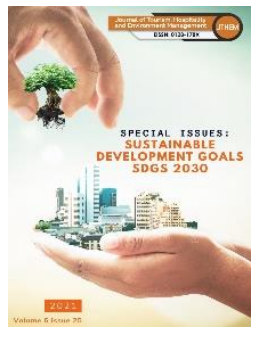

\author{
JOURNAL OF TOURISM, \\ HOSPITALITY AND \\ ENVIRONMENT MANAGEMENT \\ (JTHEM) \\ www.jthem.com
}

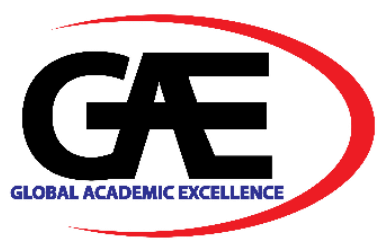

\title{
SHIFTING THE NATIONAL HIGHER EDUCATION LANDSCAPE IN FACING CURRENT CHALLENGES AND MARKETABILITY STRATEGIES OF COVID-19 PANDEMIC ERA GRADUATES
}

\author{
Irma Wani Othman ${ }^{1 *}$ \\ 1 Centre for the Promotion of Knowledge and Language Learning, Universiti Malaysia Sabah, Malaysia \\ Email: irma@ums.edu.my \\ * Corresponding Author
}

\section{Article Info: \\ Article history: \\ Received date: 01.07.2021 \\ Revised date: 16.08.2021 \\ Accepted date: 30.09.2021 \\ Published date: 31.10 .2021 \\ To cite this document: \\ Othman, I. W. (2021). Shifting The National Higher Education Landscape In Facing Current Challenges And Marketability Strategies Of Covid-19 Pandemic Era Graduates. Journal of Tourism, Hospitality and Environment Management, 6 (25), 139-156.}

DOI: 10.35631/JTHEM.625011.

This work is licensed under CC BY 4.0 (c) 2
Abstract:

This paper discusses the shift of the National Higher Education landscape in facing the current challenges and marketability strategies of Covid-19 pandemic era graduates. The submission is therefore aimed at discussing Malaysia's experience as a country that has to face various challenges in mainstreaming and expanding the National Higher Education's continuity strategically in the country's uncertain economic climate scenario. Secondary data content analysis methods utilise the results of journals, reports, books, interviews, online news and other printed materials. Underlying the background of the inaugural study, a selection of significant issues lays justification that includes arguments focused on (i) MOHE challenges facing the Covid-19 pandemic Issue, (ii) Covid-19 pandemic era graduate marketability strategy, and (iii) MOHE incentives to assist students in facing the bleakness of Covid-19 pandemic. Disputation of the target of the discussion thoroughly emphasises the relevance of MOHE initiatives in reducing the unemployment rate, especially among high quality graduates where the group will make a huge contribution to the development and economy of the country. The future direction of such studies should focus on the essence of further debate on the role of the education sector and institutions of higher learning as a field for society to develop knowledge, thus giving a positive impact to produce graduates with intellectual, physical, emotional and spiritual potential.

Keywords:

National Higher Education, Ministry of Higher Education (MOHE), University Graduates, Covid-19 Pandemic 


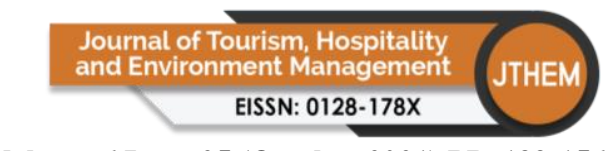

Volume 6 Issue 25 (October 2021) PP. 139-156

DOI 10/35631/JTHEM.625011

Special Issue: Sustainable Development Goals (SDGS) 2030

\section{Introduction}

High quality graduates make a great contribution to the future development of the country. All parties must play an important role in educating their children to have a high regard for personal, family and national development (Hashim, Chang \& Abd. Rahman, 2016). This indirectly trains them mentally and physically to face various challenges such as the Covid-19 pandemic and is able to ensure that the country always has the backbone of the leadership of developed countries in the future. From a future perspective, graduates with higher education are not only skilled, versatile and hands-on, but also colours the country's professional industry landscape by carving big names and becoming icons in various fields through their positions and contributions to the country (Othman, Yusoff, Mohd Shah, Esa, Ationg, Ibrahim \& Raymond Majumah, 2021). There is no doubt that versatile graduates make huge contributions to society and the country in various fields (Ali, Che' Rus, Haron \& Mohammad Hussain, 2018).

Our country's HEIs place emphasis on the field of knowledge, profession and individual skills to learn, understand, master and practice them wisely in producing quality graduates for society regardless of religion, race and culture in Malaysia (Abdul Rauf, \& Abdul Rauf, 2012). The university also plays a very high role in producing quality and thoughtful graduates in the development of the country. This is to ensure that this generation can lead the country towards excellence in terms of national development and the intellect of the society in the future. This paper discusses the shift of the National Higher Education landscape in facing the current challenges and marketability strategies of Covid-19 pandemic era graduates. The submission is therefore aimed at discussing Malaysia's experience as a country that has to face various challenges in mainstreaming and expanding the National Higher Education's continuity strategically in the country's uncertain economic climate scenario (Mohd Shah, Othman, Yusoff, Ationg, Abu Bakar, Esa \& Abang Muis, 2021).

\section{MOHE Agenda Focus on Facing Covid-19 Pandemic Issues}

The coronavirus that hit the world since early 2020 is a new challenge that needs to be faced by all sectors in Malaysia, including the education sector (Adnan \& Anwar, 2020). The issue of the Covid-19 pandemic is a new history that has never happened or been experienced by the Ministry of Higher Education (MOHE) and Higher Education Institutions (HEI) before. The sudden outbreak of the Coronavirus pandemic caused the MOHE to be unable to prepare in advance to face the Covid-19 pandemic. MOHE faces various new challenges in tackling the Covid-19 pandemic, especially in the education sector in HEIs (Wan Ya Shin, 2020).

\section{MOHE's New Challenges in Addressing the Covid-19 Pandemic}

The Movement Control Order (MCO) which has been enforced by the government in preventing the movement of the people in order to reduce the spread of virus. The MOHE faces a big challenge when it comes to thinking about or emphasising the safety aspects of students who are on campus when the MCO is announced. MOHE also needs to ensure that the close care of students needs to be given attention because it involves the safety of all students so as not to face the risk of Covid-19 infection. MOHE provided food and beverages to students who were stranded in their respective university campuses due to not being able to move anywhere during the MCO period in March 2020 (Berita Harian, 2020j). 


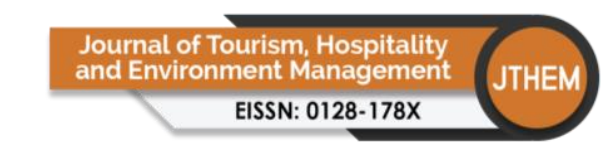

Volume 6 Issue 25 (October 2021) PP. 139-156

DOI 10/35631/JTHEM.625011

Special Issue: Sustainable Development Goals (SDGS) 2030

In addition, the biggest challenge for MOHE was when the Coronavirus outbreak was heating up in early 2020 involving the repatriation of thousands of students stranded in their respective university campuses (Berita Harian, 2020k). MOHE also needs to consider the unforeseen risks to ensure that all students are in a safe condition to be sent back to their respective homes. A very neat and orderly delivery process must be taken by imposing strict controls and must be guided by the rules set by the government, which is in accordance with the Standard Operating Procedures (SOP).

MOHE in collaboration with the university and the Royal Malaysian Police (PDRM) managed to send almost 100,000 students to their homes in safe conditions (Astroawani, 2021c). Besides that, the closure of almost all sectors in Malaysia including the education sector during the MCO period in March 2020 posing a new challenge to MOHE when face-to-face Teaching and Learning (PdP) had to be postponed and closed temporarily to curb the increase in the spread of Covid-19 (Berita Harian, 20201). This clearly challenged MOHE on how to continue the PdP process when no movement is allowed during the MCO period. MOHE had to review the education system whether in Public Universities, Private Institutions of Higher Learning, Colleges and Polytechnics according to the new norms when students and academic staff have to study and teach from their homes (Noordin, Hashim \& Abd Latib, 2020). Platforms or digital mediums such as Google Meet, Google Classroom, Zoom, Webex and Microsoft Teams are used to ensure that PdP continues even if it does not involve physical meetings. MOHE also strives to ensure that PdP does not stop due to Covid-19 causing the existence of PdP online or virtual (Hamat, Mahlan \& Ch'ng, 2020). Another challenge faced by the MOHE is to ensure that no student is left out to follow PdP online during the bleak period that hit the whole country.

\section{Teaching and Learning Challenges During the COVID-19 Pandemic}

The education sector is not left behind when it comes to accepting or adapting to the new norms in the PdP session after the Covid-19 pandemic hit the whole world, including Malaysia. The PdP challenge begins when MOHE introduces PdP session online or through virtual meetings (Noordin, Hashim \& Abd Latib, 2020). However, this poses a challenge when there is a digital divide involving students from urban and rural areas or a measure of rich and poor economies (Zulkifli, Hamzah \& Abdul Razak, 2020). A very prominent challenge faced by most students is the challenge to access the internet. Internet access problems are usually faced by students from rural or inland areas due to low internet access or weather problems do not permitted (Thannimalai, \& Baloh, 2021). Thus, for students whose residential areas have good internet access, internet data speeds will decrease when they have to share the same data if they have many siblings. It clearly affects the speed and smoothness of internet access (Othman, Yusoff, Mohd Shah, Mokhtar, Abang Muis, Marinsah \& Marzuki, 2021).

Not only that the challenge faced during PdP from home is that there are students who face financial problems. The group with financial problems is usually those who come from ow income families or the B40 groups (Thannimalai, \& Baloh, 2021). Online learning requires high internet access and the use of large data plans. The purchase of data is very costly, especially for students who have many siblings in a family. In addition, underprivileged students also face challenges when there is no device that needs to be used to attend classes virtually or obtain digital learning materials (Othman, Esa, Ationg, Ibrahim, Lukin \& Abdul Hamid, 2021). The cost of purchasing devices such as smartphones or laptops are expensive 


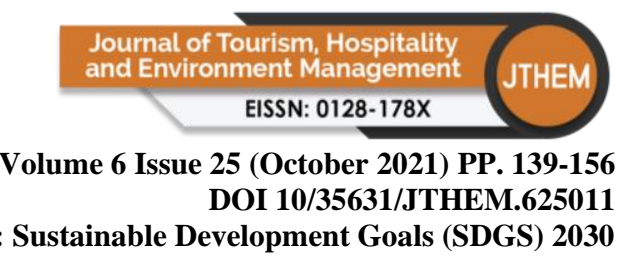

and makes it difficult for students to engage in online PdP sessions (Maslan, \& Mohd Nor, 2020).

In addition, an unconducive learning environment or space is also one of the difficult challenges for students to stay focused during lectures or PdP sessions. Noise interference in the surrounding conditions reduces the concentration of students during the learning session. Although MOHE and the university managed to create an initiative to continue lecture sessions during the MCO period by creating PdP online or from home, another challenge faced is the deterioration of communication between students and students, and students with lecturers (Yusoff, Othman, Mohd Shah, Esa, Abang Muis, Marinsah \& Ramlie, 2021; Mohd Nasir \& Mansor, 2021). Two-way communication becomes ineffective due to no face-to-face or physical interaction. The difficulty in maintaining communication through virtual PdP has also reduced the camaraderie between students and lecturers. The Covid-19 pandemic not only posed many challenges to the students but also affects the academic staff such as lecturers. This is because the use of technology or online teaching is a mandatory practice for academics, especially when online PdP has become a new norm that students and educators need to get used to (Mohd Nasir \& Mansor, 2021).

The challenge of teaching during the pandemic had to be faced when educators were unable to provide learning materials to students physically. They need to provide teaching materials such as lecture notes or exercises in digital form that can be accessed by all students. Lecturers also need to master technology when it comes to giving lectures online using applications that were previously rare or likely never used by lecturers before. Another challenge faced by educators during the pandemic is that the way of assessing student performance is significantly different than before the Covid-19 virus hit the country (Al-Mashhadani \& Khamis, 2020). Lecturers also need to re-examine methods for assessing student performance such as applying continuous assessment to students (Othman, Mohd Shah, Yusoff, Esa, Ationg, Ramlie \& Abdul Rahman, 2021).

\section{Impact of COVID-19 on HEIs \& Students}

COVID-19 which has hit the country since the beginning of 2020 not only affects or impacts the country's economic sector, but the education sector has also been affected (Pokhrel, S., \& Chhetri, 2021). The Covid-19 pandemic not only affects all students but also the HEIs in the country. Online or home-based learning created as a result of the Covid-19 pandemic puts pressure on a handful of students (Quah, 2020). Students facing stress are those who face low internet access problems, especially for students living in rural areas. Furthermore, internet access is a financial necessity when students have to purchase data at a high cost (Yahaya \& Adnan, 2021). Students' mental health was also disturbed due to lack of physical communication with peers, particularly involving the need for discussion sessions (Johari \& Ahmad, 2019).

In addition, the current use of technology in online PdP requires skills to use. For example, the issue of a university student from Universiti Malaysia Sabah, Veveonah Mosibin who became viral following the student when she had to climb a tree in her village in order to get good and stable internet access because she had to sit for an exam online (Berita Harian, 2020a). HEIs are also not the least bit affected by the aftermath of the Covid-19 pandemic which is spreading in the country. HEIs area affected by Covid-19 when HEI management systems need to be 


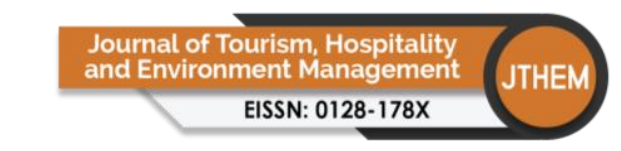

Volume 6 Issue 25 (October 2021) PP. 139-156

DOI 10/35631/JTHEM.625011

Special Issue: Sustainable Development Goals (SDGS) 2030

reviewed and re-examined based on new norms of using PdP from home or virtually. Not only that, the Covid-19 pandemic affected the economy of HEIs when the university's internationalisation agenda had to be postponed due to the absence of admission of international students coming from abroad (Wan Ya Shin, 2020). This has to some extent affected the university's finances.

Research and innovation activities also had to be postponed because any movement during the MCO period was strictly prohibited making movement into the research laboratory impossible. Furthermore, activities within the university involving face-to-face meetings were not allowed and had to be postponed or stopped. HEIs also need to plan and intensify the level of effectiveness of online PdP sessions for HEI students nationwide. The quality of student learning shows a decline when online learning is used as a method to replace physical learning in HEIs (Sri Nurhayati Selian, Hutagalung \& Rosli, 2020). The quality of students learning is affected by factors such as internet access problems, unconducive learning environment and other disturbances that affect students' concentration as well as affect students' performance (Othman, Ibrahim, Esa, Ationg, Mokhtar, Mohd Tamring \& Sharif Adam, 2021). There are also some programmes in HEIs that require entry into the laboratory for the purpose of clinical training which cannot be done due to restricted movement during the MCO period (Utusan, 2020).

The Covid-19 pandemic also caused the registration of new students to HEI to be delayed until the rate of infection or transmission of Covid-19 gradually recovers or decrease. However, the Covid-19 pandemic that hit the country also showed a positive side or blessing in disguise. One of them is that online PdP can increase the use of technology in the education sector. Students and lecturers able to improve their skills in using IT in accordance with the current era of globalisation which emphasises in science and technology such as developed countries in the world (Bahrom, 2020). The use of technology in online PdP sessions also sharpens a handful of students in the field of information technology when there are students who are skilled and have talent in the field of editing to produce creative and high-quality videos. In addition, learning activities from home also help students in self-training as well as independence and responsibility in their learning. In fact, after digital mediums such as Cisco Webex, Google Meet, Facebook Live and various other platforms that are increasingly commonly used by students and academics, there are many sharing sessions or public knowledge lectures conducted virtually (Bahrom, 2020). Although the Covid-19 pandemic has affected HEIs and students, there is still a positive impact that is received and can be applied by HEIs and students.

\section{MOHE Measures to Intensify Student Efforts During the COVID-19 Pandemic}

MOHE actively took various approaches to help students during the bleak period when the Covid-19 pandemic hit the country. Efforts are taken to help students who are facing difficulties. The financial injection channeled to the MOHE to help students especially economic assistance, can reduce students' anxiety in the face of the Covid-19 pandemic. MOHE provides data plan assistance which is very helpful for students who have financial problems to buy a data plan, especially for students in the B40 group (Astroawani, 2020). With the help of a data plan, students can access the internet for the purpose of attending online lectures or downloading learning materials. Apart from data plan assistance, MOHE also offers one-off financial assistance of RM200 to HEI students (Bernama, 2020). Furthermore, students who have problems with the lack of devices are also assisted by the MOHE to reduce the cost of purchasing gadgets which are expensive.

Copyright $\odot$ GLOBAL ACADEMIC EXCELLENCE (M) SDN BHD - All rights reserved 


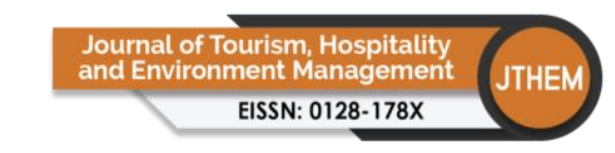

Volume 6 Issue 25 (October 2021) PP. 139-156

DOI 10/35631/JTHEM.625011

Special Issue: Sustainable Development Goals (SDGS) 2030

MOHE also increased efforts to examine the grievances and difficulties faced by students in order to help students studying at HEI. Therefore, MOHE agreed to reduce the rate of payment of tuition fees such as eliminating hostel fees, especially for students who do not stay on campus (Berita Harian, 2020b). Meanwhile, students who were on campus were given food and beverage delivery assistance according to the SOPs that have been set in their respective residential colleges because they were not able to go out to buy food (Berita Harian, 2020c). MOHE also received great offers from telecommunication companies to provide free internet package assistance for the students to use. In order to alleviate the burden borne by parents and students to remain following PdP online during the Covid-19 pandemic, MOHE has allocated a total of RM24 million for the cost of data plan assistance to HEI students (Berita Harian, 2020d).

MOHE is stepping up measures to help students from time to time so that no one is left behind during online PdP during the Covid-19 pandemic period which is still existing to this present moment. After implementing a lot of assistance to students, MOHE has also provided a total of 225,784 units of SIM cards that were distributed to HEI students in collaboration with telecommunication companies, YTL Foundation and Lembaga Tabung Haji (Sinar Harian, 2020a). Meanwhile, there are students who received financial assistance to purchase data plans. In addition, a total of RM13 million has been allocated to finance the cost of providing devices such as laptops to B40 students in need (Berita Harian, 2020d). MOHE also made other approaches such as postponing the repayment of loans from the National Higher Education Fund Corporation (PTPTN) (Hmetro, 2021a). MOHE took the step to ease the burden of students to pay due to constraints or restricted movement during the MCO period (Yusoff, Othman, Jupiter \& Mokhtar, 2021). It is clearly seen that the assistance provided by the government and MOHE is a proactive measure to ensure that no student will be left out and lagged in learning, while the country still unable to eliminate the spread of Covid-19 in the community.

\section{Marketability Strategy of Graduates in Covid-19 Pandemic Era}

Unemployment is someone who wants to work but does not get a job. They are classified as the labour force of a country, that is, those who aged between 15-65 years who are willing to work (Ahmad, Ali \& Hamzah, 2011). In a society where most people can make a living by working with others, being unemployed would be a serious problem (Othman, Ationg, Esa, Hajimin \& Abang Muis, 2021). Its' negative effects include loss, feelings of rejection and personal failure, and therefore unemployment is widely used to measure employee welfare. The unemployment rate also indicates the level of efficiency in the use of human resources of a country and makes an index for economic activity (Othman, Yusoff, Esa, Ibrahim, Mohd Tamring \& Mohd Shah, 2020). MOHE has the instrument to conduct a survey questionnaire within 6 months from the date of graduation (Hmetro, 2021b).

\section{Ministry of Higher Education Initiative to Reduce the Unemployment Rate Among Graduates}

The study is related to the marketability of graduates conducted each year to examine how many graduates have graduated and successfully obtained employment opportunities (Othman, Yusoff, Abdul Hamid, Awang \& Jupiter, 2018). In 2016 to 2018, the percentage rate of marketability of graduates is located at the level of 80.0 percent and above and there is a high increased occurred in 2019 which is 86.2 percent (MOHE, 2021a). However, in $2020 \mathrm{MOHE}$ Copyright @ GLOBAL ACADEMIC EXCELLENCE (M) SDN BHD - All rights reserved 


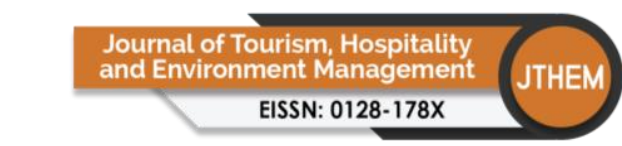

Volume 6 Issue 25 (October 2021) PP. 139-156

DOI 10/35631/JTHEM.625011

Special Issue: Sustainable Development Goals (SDGS) 2030

has conducted another Graduate Tracking Study by recording a marketability rate of 84.4 percent, which is slightly lower than the marketability rate in the previous year (MOHE, 2021a). Hence, following to the pandemic that hits our country at this moment, the data recorded was found to have exceeded the initial projection drawn up by the MOHE which is 75 percent (MOHE, 2021a). For them, the 1.8 percent decline in the marketability rate in 2019 to 2020 is very unique and not as significant as expected due to the country's unstable economic situation and the impact of this pandemic has also closed job opportunities for university graduates to find employment (MOHE, 2021a).

The government should be concerned as to provide assistance to graduates who have not found a job or are unemployed (Othman, Awang, Hamid, Yusoff \& Jupiter, 2018). This assistance will probably help them to continue surviving before getting a permanent job and having a salary that can cover their living expenses. In this era of the Covid-19 pandemic, most of the graduates who have graduated will not directly get jobs because the country's economic sector is slightly declining with the closure of shops and offices. This is said to be so in order to curb the spread of Covid-19 disease which could lead to death. This is to ensure the safety and health of all communities in Malaysia regardless of religion, race and culture (Othman, Jupiter, Awang \& Yusoff, 2017). Malaysia has also formulated a vision 2020 as a plan for the country's development, but the Covid-19 pandemic has had significant implications for the country's economic and development sectors (Wan Ya Shin, 2020). This has led to an increase in the unemployment rate in Malaysia.

The Malaysian government has announced a moratorium on loan payments and PTPTN loan deferral assistance for graduates who have graduated because they have not found employment yet (Hmetro, 2021a). The postponement is part of the Prihatin Rakyat Economic Stimulus Package (PRIHATIN) which aims to protect the people, support business and strengthen the national economy (Berita Harian, 2020f). In addition, the prescribed loan repayment moratorium is also to reduce the financial burden for the people especially the graduates. At the same time, it can help cash flow problems that arise in the business as a result of the implementation of the Movement Control Order (MCO).

Various initiatives implemented by the Ministry of Human Resources to the unemployed was to ensure that they get equal rights in society (Berita Harian, 2020e). Under the Recruitment Incentive, financial incentives were given by category namely, the apprenticeship programme which involves RM600 per month, local job seekers aged 40 and above was given RM1000 while for local job seekers among the disabled was given RM1000 (Berita Harian, 2020e). The implementation of this incentive involves hiring employees who are unemployed for at least 2 months. The number of workers who are temporarily unemployed has increased to 146,200 people compared to November 2020 (142,000 people) due to the implementation of movement control order during the month as well as school holidays and short festive holidays (Berita Harian, 2021a). This group of unemployed is most likely unable to work. As the country experiences slower labour demand in 2020 due to the negative impact of the Covid-19 pandemic, the number of unemployed recorded an increase of over 200,000 people (Berita Harian, 2021a).

\section{PTPTN Repayment Deferment}

In addition, the MOHE has deferred PTPTN repayment for qualified borrowers and has also extended the deferment period for three months. There is no denying that the COVID-19 Copyright @ G GLBAL ACADEMIC EXCELLENCE (M) SDN BHD - All rights reserved 


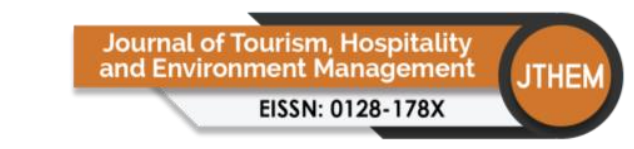

Volume 6 Issue 25 (October 2021) PP. 139-156

DOI 10/35631/JTHEM.625011

Special Issue: Sustainable Development Goals (SDGS) 2030

outbreak has impacted various parties such as retrenchment. Therefore, the Minister of Higher Education, Datuk Seri Dr. Noraini Ahmah has stated that the decision was taken due to the government's concern for PTPTN borrowers affected by the COVID-19 pandemic. In fact, there are also long service employees and officers from companies in our country have been laid off and retrench because the profits earned since this pandemic season cannot cover and pay the salaries and allowances of employees or officers.

During the year 2020, the MOHE has implemented intervention measures such as holding various programmes under generation, from other ministries, the Social Security Organisation (SOCSO), the industry, the university and so on (Berita Harian, 2020e). Among the measures to increase employment opportunities implemented by the MOHE is to implement the Entrepreneurship Development Programme by collaborating with Perbadanan Usahawan Nasional Bhd which will train graduates to venture into entrepreneurship and the Ministry of Entrepreneur and Cooperative Development (MEDAC) (MOHE, 2020b). Apart from that, the MOHE has also implemented a job matching programme and held cooperation with the Social Security Organisation (SOCSO) as well as held a graduate marketability programme in collaboration with other strategic partners of the ministry (Hmetro, 2020). This is because the ministry is very committed in increasing the marketability rate for graduates to ensure that graduates will get a job position in accordance with the qualifications and achievements achieved (Othman, Jupiter \& Mohd Suki, 2019).

In this regard, MOHE has established a collaboration with Malaysia Technology Development Corporation (MTDC) by implementing the Industrial Graduate Marketability 4.0 Programme in 2018 (MOHE, 2021b). The programme has given positive results by recording a total of 286 participants out of the actual number of 412 graduates who were offered jobs on an apprenticeship and have received permanent job offers (MOHE, 2021b). In this year's programme, a total of 280 graduates from Public Higher Education Institutions (PHEIs) have been offered apprenticeship jobs in 189 local companies in our country and have to go through four phases of training such as Career Enhancement Workshops, Industry Attachment, Industry Speed Interview and Job Placement (MOHE, 2021b). This is said to be so because graduates who have participated in such programmes will have a bright opportunity to be given a job match that suits the demands of the industry today and apprenticeship which will eventually be offered to become permanent employees in local companies if they show good and brilliant performance.

\section{Empowering the Entrepreneurship Agenda to Become a Career Branch with Great Potential for Graduates}

Empowerment in the field of entrepreneurship is a career branch with great potential for students and graduates in Malaysia. This is because, the field not only provides lucrative income generation to entrepreneurs alone, but it is also able to create employment opportunities for the community with their involvement in business. To achieve the objective of making the field of entrepreneurship as a broad career branch, the MOHE has implemented the Institute of Higher Learning (HEI) Entrepreneurship Action Plan in 2021-2025 to ensure the continuity of the empowerment of this entrepreneurship agenda to run smoothly in HEIs in Malaysia (Berita Harian, 2021b). Therefore, the government's hope is that this action plan will continue to be able to elevate the field of entrepreneurship in HEIs as a whole through the strengthening of a complete entrepreneurial ecosystem when faced with the volatile job market due to the Covid19 pandemic.

Copyright $\odot$ GLOBAL ACADEMIC EXCELLENCE (M) SDN BHD - All rights reserved 


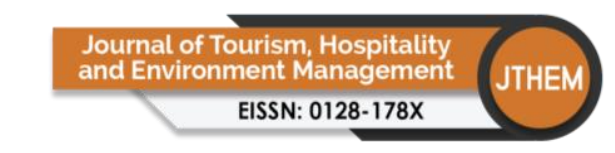

Volume 6 Issue 25 (October 2021) PP. 139-156

DOI 10/35631/JTHEM.625011

Special Issue: Sustainable Development Goals (SDGS) 2030

At the same time, the government has joined hands to channel allocation warrants to MOHE of RM100 million to implement the Ministry of Higher Education and Career Advancement Programme (MOHE-CAP) which is also a programme for generation under the People Empowerment initiative through Skills Programme and Skills Improvement which has reached RM2 billion (MOHE, 2020a). The MOHE-CAP Generator Programme that has been introduced is a unique programme because the graduates will be ensured to get a job after they finish attending the courses set by the companies that will take the graduates as permanent employees (MOHE, 2020a). For example, courses like Smart Trucker. This course focuses on teaching related to the skills required by the logistics company that will issue a "Letter of Commitment" (LOC) to MOHE. Upon completion of the course, these graduates will be offered to work permanently with the logistics company if they show good performance. Local university graduates who have made a name for themselves as successful entrepreneurs deserve to be made icons to increase the spirit of young graduates to follow in their footsteps.

There are various examples and inspirations that can be emulated by graduates such as the story of a graduate from Universiti Teknologi Malaysia (UTM) that is Arif Tukiman who is 28 years old is the chief executive officer and owner of Run Cloud company which offers "cloud server" and "web deployment" (UTM, 2018). The RM20 million company he operates now manages more than 230,000 web applications from more than 100 countries including the United States, United Kingdom and India which are the company's main markets. In this regard, the government and MOHE call on university graduates out there who have not been fortunate enough to get a job, should use this opportunity to increase their skills and help improve their own marketability by applying for this MOHE-CAP programme through the Graduates Reference Hub portal for Employment and Training (GREAT) (Berita Harian, 2020g).For example, university students and graduates should be wise in choosing job opportunities and not be too picky in order to achieve excellent success and a bright future without us realising it.

\section{MOHE Incentives to Students Facing Covid-19 Pandemic Trouble}

The Ministry of Higher Education (MOHE) has undertaken various initiatives in assisting students in facing the constraints of the COVID-19 pandemic. Among the assistance that has been given is in terms of finance.

\section{MOHE Assistance in Terms of Finance}

The first step taken by MOHE is to fully bear the payment for the UPU Online application process and the purchase of a UNIK ID number worth RM15.60 to all applicants who have passed Sijil Pelajaran Malaysia (SPM), Sijil Tinggi Pelajaran Malaysia (STPM), Asasi, Sijil Tinggi Agama Malaysia (STAM) and others for academic session 2021/2022 (Astroawani, 2021a). Liabilities incurred by the MOHE is up to RM5.0 million equivalents to 300,000 students who applied (Astroawani, 2021a). This is because the UPU Online processing fee has been charged to previous applicants to obtain a UNIK ID number at Bank Simpanan Nasional $(B S N)$ as a condition to fill in the application form to continue studies at Public Institutions of Higher Learning (HEI) and Public Skills Training Institutions (ILKA) (Astroawani, 2021a). Therefore, MOHE hopes that this measure can reduce the burden of prospective students to further their studies and achieve outstanding success due to the pandemic that hit our country. 


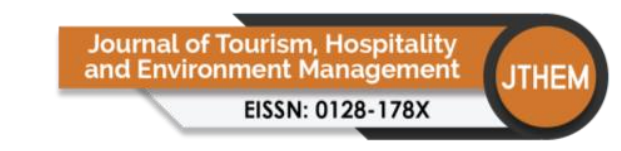

Volume 6 Issue 25 (October 2021) PP. 139-156

DOI 10/35631/JTHEM.625011

Special Issue: Sustainable Development Goals (SDGS) 2030

As we know, students are also not spared from facing financial crisis during this pandemic. Therefore, the MOHE has tried to ease the burden of students by reducing the amount of fees that need to be borne. Among the incentives given by them to university students during this pandemic is to reduce tuition fees at Public Universities which is a minimum rate of $15 \%$ (Berita Harian, 2020b). This includes registration fees, semester fees, hostel fees and so on. Therefore, the cost of education for students is no longer so high because most of these students only attend lectures online and no longer using the facilities provided by the university. At the same time, students also no longer using dormitories, sports facilities, laboratories and lecture rooms that require electricity costs to hold lectures. The Ministry of Higher Education (MOHE) and the Ministry of Finance (MOF) have decided to reduce the fee by 15 percent which also involves a government allocation of around RM72 million (Berita Harian, 2020b). The results have benefited 533,318 students of Public Institutions of Higher Learning (HEI) nationwide (Berita Harian, 2020i).

Meanwhile, for students who find it difficult to get good internet access, students are also provided with internet facilities to attend PdP online as well as internet plans for the use of students who are allowed to return to HEI. According to the National Student Consultative Council (MPKK), the number of students who have returned to their homes has reached 80 percent and no longer use all the facilities provided at the university for the PdP process. Not only that, but the government and MOHE have also provided financial assistance through the People's Caring Economic Stimulus Package (PRIHATIN) assistance fund. One-off assistance of RM200 was given to eligible students where payment was made through the students' personal bank account only (Berita Harian, 2020d). The allocation provided and given to these students amounts to RM270 million and will be channelled to students at various levels of higher education including matriculation, Community Colleges, Polytechnics, Public Institutions of Higher Learning and also Private Institutions of Higher Learning (Berita Harian, 2020h). The government hopes that the fund to some extent can help ease the financial burden of students in facing the constraints that occur during this pandemic.

\section{MOHE Initiative in Terms of Students Welfare}

Apart from the financial aspect, the Ministry of Higher Education (MOHE) has also taken steps to help students in terms of their welfare in facing the COVID-19 pandemic. Among the MOHE's efforts in helping students can be seen through the preparation and activation of the COVID-19 Operation Room in every Institute of Higher Learning (HEI). The Operation Room is activated to help students who are in HEI and operate for 24 hours a day with the involvement of 70 staff (Astroawani, 2021b). Not only that, but the assistance of supplies and provision of cafeteria and grocery store facilities is also a guarantee of the MOHE to take care of the welfare of students who live on campus. Apart from that, students outside the university are also not left behind from receiving assistance provided by the MOHE.

Among the initiatives undertaken by the MOHE is the establishment of an off-campus management unit. All public HEIs have produces a special portfolio that aims to manage offcampus student affairs in a more systematic and orderly manner. In addition, the MOHE has also launched the Student House Portal in an effort to address the issue of management and safety of students who do not staying in hostels provided on campus (MOHE, 2021c). Through this portal, students can seek advice, find a room or house to rent easily and keep the rental price at an affordable rate. Among the benefits of this portal is a special database at the university level can be ascertained for example in terms of accommodation location, distance Copyright (C) GLOBAL ACADEMIC EXCELLENCE (M) SDN BHD - All rights reserved 


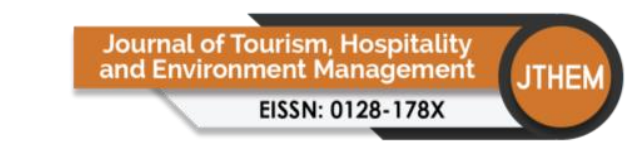

Volume 6 Issue 25 (October 2021) PP. 139-156

DOI 10/35631/JTHEM.625011

Special Issue: Sustainable Development Goals (SDGS) 2030

to access university facilities and safety aspects of off-campus students which is the main focus for the MOHE (Othman, Jupiter, Abdul Hamid, Yusoff \& Awang, 2018). This step has been taken by the MOHE with the hope that no students will be left out and have a conducive place to live in terms of quick and easy access as well as their well-being can also be more guaranteed.

According to Datuk Seri Dr Noraini Ahmad, the MOHE has also joined hands with the Malaysian Public Universities Housing Council (MAPUM) by developing a comprehensive guideline for the management of off-campus students (Sinar Harian. (2020b). These guidelines have been drafted by taking into account of five main aspects, namely off-campus student development, off-campus student services, off-campus student welfare management, rental housing management and off-campus student community networking (Othman, Esa, Ationg $\&$ Muda, 2021). Not only that, but the MOHE together with 20 public universities have also established a unit, the Off-Campus Management Unit (UPLK) which acts as an administrator, advisor, housing counselling service to monitor the implementation of programmes and activities of off-campus students so that management unit development initiatives off-campus students can be implemented more efficiently (Sinar Harian. (2020b).

The Ministry of Higher Education (MOHE) has also taken other measures to ensure the welfare of students is always guaranteed, for example by channelling food aid for those stranded on campus. It is understood that the MOHE has agreed to bear the food and beverages of students who had to be on campus due to the COVID-19 pandemic and throughout the MCO period. The food and drinks were distributed to students in various methods according to their respective universities. There were several universities that distributed ready-cooked food, and there were also other universities that use the coupon giving method where students can get their food at cafes or canteens on campus (Berita Harian, 2020j). These steps have to some extent helped alleviate the burden and anxiety of students affected by this increasingly contagious pandemic.

Mental health is one of the important aspects that need to be emphasised especially among students (Sinar Harian, 2020b). The COVID-19 pandemic has undeniably had an impact on the mental health of students, especially when PdP sessions are conducted online. Students who could not afford to return to their hometowns and had to stay in hostels during the pandemic period were also among the factors that contributed to the increased levels of stress and depression. The MOHE has emphasised that counselling services be provided to listen and give advice to students who need emotional support (Sinar Harian, 2020b). As such, many universities have provided special counselling services for their students so that the mental and emotional health of students is more stable in facing the challenges faced during this pandemic (Othman, Yusoff, Marinsah, Mokhtar, Ramlie \& Mohd Shah, 2020).

In addition, the MOHE has also taken the initiative for HEI students who want to go back to campus to start their learning sessions by exempting them from paying screening tests for detection of COVID-19 pandemic. The group of students who were exempted from the payment of swab test consists of 18,600 people and is divided into three categories of students with backgrounds from Sabah, Sarawak, Labuan and the Peninsular (Berita Harian, 2021c). The students involved are new students who will start the learning session physically and this detection test involves an estimated cost of RM2.79 million where the test will be implemented at the facilities of the Ministry of Health $(\mathrm{MOH})$ (Berita Harian, 2021c).

Copyright (C) GLOBAL ACADEMIC EXCELLENCE (M) SDN BHD - All rights reserved 


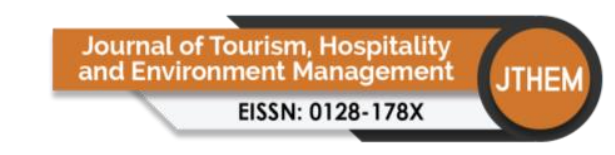

Volume 6 Issue 25 (October 2021) PP. 139-156

DOI 10/35631/JTHEM.625011

Special Issue: Sustainable Development Goals (SDGS) 2030

The initiative to take the free COVID-19 pandemic detection test which has been decided by the MOHE in collaboration with the MOH has made it compulsory for every student involved to carry out the test before starting the study session. Finally, the MOHE has also allocated university hospitals under the ministry to be used to screen students and outsiders. There are 6 University Teaching Hospitals (HPU) which were given the responsibility as Vaccination Centres (PPV) to help the government implement the National COVID-19 Immunisation Programme. Among the HPUs involved as PPV are Universiti Teknologi Mara (PPUiTM), Pusat Perubatan Universiti Malaya (PPUM), Hospital Universiti Sains Malaysia (HUSM), Sultan Ahmad Shah Medical Centre @IIUM (SASMEC @ IIUM), Hospital Canselor Tuanku Muhriz, Universiti Kebangsaan Malaysia (HCTM UKM) dan Hospital Pengajar Universiti Putra Malaysia (HPUPM) (Berita Harian, 2021d). With the involvement of HPU as PPV, the step taken by the MOHE is a systematic step in helping the government, students and the public to get a dose of vaccine injection for free.

\section{MOHE Assistance from the Aspect of Devices and Data Plans}

The challenges faced by students come in many forms. Besides financial problems and their welfare guarantees, the students also faced a very difficult situation in terms of internet accessibility and gadgets used for lecture sessions. As it can be seen, the PdP sessions that have been ordered to be conducted online only was not a good news for a handful of students especially those from the B40 group. Due to this, the MOHE has tried various assistance so that every student does not left out of learning. A total of RM24 million has been allocated by the MOHE for Data Plan Assistance to students from the B40 category which is a total of 320,396 in an effort to ensure that they have good internet access and accessibility while attending lectures online (Berita Harian, 2020d).

Through this assistance, the Minister of Higher Education Datuk Dr Noraini Ahmad has explained that the MOHE in collaboration with telecommunication companies, Yayasan YTL and Lembaga Tabung Haji has distributed SIM cards amounting to 225,784 to students (Berita Harian, 2020d). However, the remaining students who did not get the card will be given cash so that they can also afford to buy a data plan for learning purposes. Apart from data plans, there were also a handful of students who do not have a device to attend lectures such as a laptop. Due to this, the MOHE has taken the initiative to provide free laptop assistance to students in the B40 category. According to Datuk Dr Noraini Ahmad, this assistance can be divided into three ways namely, some of them will receive the laptop assistance for free (5965 people), some of them will be given assistance in the form of cash but for the same purpose of getting a laptop (2700 people), while some of the students will receive laptop assistance in the form of financial loans where they can own the laptop at a special price for students (300 people) (Berita Harian, 2020d).

Due to the large number of students in the country, the MOHE has estimated a total fund of RM13 million in an effort to fund the provision of this device to students in need (Berita Harian, 2020d). Most of the assistance given to students is the result of cooperation between MOHE and Yayasan Sukarelawan Siswa (YSS) by launching an initiative that is crowd funding through Tabung Prihatin Siswa to ensure the ability of students to continue learning online can be more secure and achieved (Berita Harian, 2020d). With such assistance, the MOHE hopes that the burden of students to bear the cost of learning can be reduced so they can study in a more conducive and comfortably. 


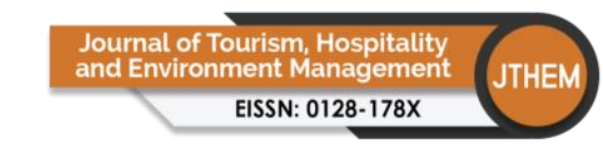

Volume 6 Issue 25 (October 2021) PP. 139-156

DOI 10/35631/JTHEM.625011

Special Issue: Sustainable Development Goals (SDGS) 2030

\section{MOHE's Initiative in the Aspect of Transportation}

The challenge of the COVID-19 pandemic has undeniably caused the MOHE and universities throughout the country to order students to continually stay in hostels provided on campus, especially for those who have a distant hometown. There were also a handful of students who were allowed to commute from campus and their residence. However, this does not mean that the MOHE does not care about the constraints faced by students. As a matter of fact, the MOHE understands the problems of the students who in turn have decided to help them return to their hometowns after the pandemic situation is not too severe. With this, a step has been taken by the MOHE by offering special flight services for students, especially for those who want to return to their respective Institutes of Higher Learning (HEI) to continue their learning sessions.

The flight offer given specially to these students involves a discount of $20 \%$ from Malaysia Airline Berhad after discussing and agreeing the proposal with the MOHE (Edubestari, 2020). In conclusion, the students will always face new challenges as long as the situation in the country affected by the COVID-19 pandemic has not fully recovered. However, the Ministry of Higher Education (MOHE) is always trying to alleviate the concerns and problems faced by students. As can be seen up to now, the MOHE has spent millions of cash in an effort to ensure that any group of students will not be left out in their study while ensuring their welfare during the pandemic period that is still ongoing. With the various forms of assistance that have been provided, students should be more enthusiastic in attending learning sessions and not waste the efforts of the MOHE in ensuring their well-being is taken care off.

\section{Concluding Thoughts}

The situation in our country as a result of the outbreak of COVID-19 is not expected to fully recover in near future, thus causing various problems from the socio-economic, educational and political aspects (Ationg, Esa, Othman \& Yusoff, 2021). The emergence and onset of the COVID-19 pandemic that hit the country has impacted many parties, especially those in the education sector such as the MOHE, lecturers and students. Undoubtedly, the COVID-19 pandemic has brought about various constraints that test the patience of students mentally and emotionally (Norhana Ahad, 2020). Students have to face challenges in various forms that can be said to be very difficult for them, especially when PdP sessions are conducted online. Therefore, the MOHE has worked hard to find ways to help students who are affected badly by this pandemic.

Various initiatives have been implemented by the MOHE in collaboration with several government bodies in an effort to alleviate the burden of students as well as alleviate the anxiety and worry that is ingrained in each student when faced with the constraints of the effects of the COVID-19 pandemic. Apart from that, the MOHE has also taken steps to help students who are experiencing difficulties and affected by the Covid-19 pandemic that has hit our country now. As discussed, the biggest issue for graduates is the difficulty of balancing supply and demand in the various sectors of employment. Therefore, there is competition in the job market because there are a number of graduates who do not meet the needs and skills required by employers.

Entrepreneurial activities play an important role in promoting the economic and social development of a country (Nor Asiah et al., 2018) negara (Othman \& Hussin, 2019). This has given a very clear picture that entrepreneurship is the main key that helps the development and Copyright (C) GLOBAL ACADEMIC EXCELLENCE (M) SDN BHD - All rights reserved 


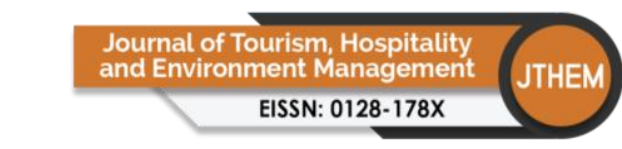

Volume 6 Issue 25 (October 2021) PP. 139-156

DOI 10/35631/JTHEM.625011

Special Issue: Sustainable Development Goals (SDGS) 2030

economic growth of a country where it is the largest contributor to the increase in gross domestic product (GDP) and able to stimulate investment while generating employment. Due to the problem of unemployment and the issue of marketability of graduates is still occurring and becoming more serious, the government has begun to encourage and provide support to graduates to venture into entrepreneurial activities as a career option. With the COVID-19 pandemic situation still raging, almost all key sectors have experienced reduced profits due to the implementation of the Movement Control Order (MCO) which aims to address the spread of this corona virus outbreak.

Therefore, looking at this situation, the graduates have to find and generate sources of income to meet daily needs. Thus, the encouragement and support given to the graduates in particular has helped them in generating sources of income as well as helping the country in reducing the rising unemployment rate in our country. Various efforts have been carried out by the government through the ministries and also non-governmental organisations (NGO) to jointly attract the interest of graduates and dare to engage in entrepreneurial activities. Graduates can also start venturing into entrepreneurial activities based on the agricultural sector (Othman \& Hussin, 2019). In fact, those who have embarked on a career in this field of entrepreneurship have indirectly provided employment opportunities to others. Not only that entrepreneurial skills are also important as they can help graduates to explore, learn and increase their added value.

At the same time, in order to produce quality graduates who meets the needs of the market and help graduates get jobs, various efforts need to be done by the Ministry of Higher Education (MOHE). Among them is the development of the Soft Skills Development Module and the Basic Entrepreneurship Cultivation Module taught in all Public Higher Education Institutes (HEI) (Syed Sahil \& Hassan, 2018). The Ministry of Higher Education (MOHE) is constantly striving to increase the employment availability of graduates. Current graduates are not only required to have academic knowledge (graduate skills) but also need to have soft skills to increase their potential. This proves that the university plays a very necessary role in producing high quality graduates to meet the job market that makes a high contribution to the country.

Education is the most important investment to ensure a better quality of life for future generations (Othman, Yusoff, Lukin, Ationg, Abang Muis \& Mohd Shah, 2020). Therefore, the Ministry of Higher Education (MOHE) continues to receive the largest allocation of RM50.4 billion or 15.6 percent of total government expenditure (Berita Harian, 2020f). These initiatives are to ensure that the present generation receives higher education in order to produce a highly educated society in the future. The education sector and institutions of higher learning play an important role in the development of a city and region. The university is a platform for society to develop knowledge, which in turn gives a positive impact to produce intellectual, physical, emotional and spiritual potential.

\section{Acknowledgement}

This article is part of the UMS and UPSI (TLS2113) collaborative publishing grant sponsorship funded by Global Academic Excellence (GAE). The authors would like to express their deepest heartfelt appreciation to Global Academic Excellence (GAE) for providing funding this publication. 


\section{References}

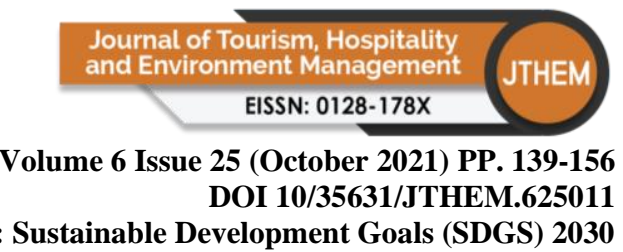

Abdul Rauf, S. H., \& Abdul Rauf, M. (2012). Keberkesanan Program Skim Latihan Graduan bagi Mengurangkan Kadar Pengangguran dalam Kalangan Siswazah. Jurnal Islam dan Masyarakat Kontemporari, 5: 3-12.

Adnan, M., \& Anwar, K. (2020). Online Learning amid the COVID-19 Pandemic: Students' Perspectives. Online Submission, 2(1): 45-51.

Ali, E., Che' Rus, R., Haron, M. A., \& Mohammad Hussain, M. A. (2018). Kebolehpasaran Graduan Pendidikan Teknikal dan Vokasional: Satu Analisis. Sains Humanika (10) 33: 9-15.

Astroawani. (2021a). KPT tanggung sepenuhnya bayaran proses UPUOnline - Menteri. Retrieved from: https://www.astroawani.com/berita-malaysia/kpt-tanggungsepenuhnya-bayaran-proses-upuonline-menteri-286810

Astroawani. (2021b). Bilik Gerakan 24 jam di IPT salur maklumat pelajar termasuk kes COVID-19 - Noraini. Retrieved from: https://www.astroawani.com/beritamalaysia/bilik-gerakan-24-jam-di-ipt-salur-maklumat-pelajar-termasuk-kes-covid19noraini-290430.

Astroawani. (2021c). Bilik IPT keluarkan surat untuk pelajar pulang beraya, tak perlu ke balai polis. Retrieved from: https://www.astroawani.com/berita-malaysia/ipt-keluarkansurat-untuk-pelajar-pulang-beraya-tak-perlu-ke-balai-polis-296782

Astroawani. (2020). PdP dalam talian: Bantuan data dan peranti bagi pelajar IPT - Dr Noraini. Retrieved from: https://www.astroawani.com/berita-malaysia/pdp-dalam-talianbantuan-data-dan-peranti-bagi-pelajar-ipt-dr-noraini-266134.

Ationg, R., Esa, M. S., Othman, I. W., \& Yusoff, M. S. (2021). Trend, Potential and Challenges of Local Languages Learning During the COVID-19 Pandemic. International Journal of Education, Psychology and Counseling, 6 (41), 103-110.

Berita Harian. (2021a). Kadar pengangguran di Malaysia meningkat. Retrieved from: https://www.bharian.com.my/bisnes/lain-lain/2021/02/784288/kadar-penganggurandi-malaysia-meningkat.

Berita Harian. (2021b). 3 teras Pelan Tindakan Keusahawanan IPT 2021-2025. Retrieved from: https://www.bharian.com.my/berita/nasional/2021/02/787816/3-teras-pelan-tindakankeusahawanan-ipt-2021-2025.

Berita Harian. (2021c). 18,600 pelajar IPT dikecualikan bayaran ujian pengesanan. Retrieved from: https://www.bharian.com.my/berita/nasional/2021/03/792831/18600-pelajaript-dikecualikan-bayaran-ujian-pengesanan

Berita Harian. (2021d). 6 hospital pengajar universiti jadi Pusat Pemberian Vaksin. Retrieved from: https://www.bharian.com.my/berita/nasional/2021/03/792547/6-hospitalpengajar-universiti-jadi-pusat-pemberian-vaksin

Berita Harian. (2020a). Video tular pelajar UMS jawab peperiksaan atas pokok. Retrieved from: $\quad$ https://www.bharian.com.my/berita/wilayah/2020/06/701039/video-tularpelajar-ums-jawab-peperiksaan-atas-pokok.

Berita Harian. (2020b). COVID-19: Yuran mahasiswa UA dikurangkan. Retrieved from: https://www.bharian.com.my/berita/nasional/2020/07/711011/covid-19-yuranmahasiswa-ua-dikurangkan.

Berita Harian. (2020c). COVID-19: Kerajaan tanggung makan, minum pelajar IPT tidak dibenar pulang. Retrieved from: https://www.bharian.com.my/berita/nasional/2020/03/667219/covid-19-kerajaantanggung-makan-minum-pelajar-ipt-tidak-dibenar. 


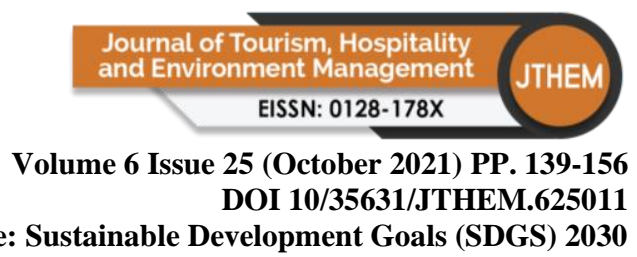

Special Issue: Sustainable Development Goals (SDGS) 2030

Berita Harian. (2020d). KPT peruntuk RM24 juta bantuan pelan data untuk pelajar IPT B40. Retrieved from: https://www.bharian.com.my/berita/nasional/2020/10/748271/kptperuntuk-rm24-juta-bantuan-pelan-data-untuk-pelajar-ipt-b40

Berita Harian. (2020e). Insentif PENJANA usaha kekal, cipta pekerjaan. Retrieved from: https://www.bharian.com.my/berita/nasional/2020/06/699379/insentif-penjana-usahakekal-cipta-pekerjaan.

Berita Harian. (2020f). Ucapan penuh Belanjawan 2021. Retrieved from: https://www.bharian.com.my/berita/nasional/2020/11/751024/ucapan-penuhbelanjawan-2021.

Berita Harian. (2020g). Graduan perlu daftar segera PENJANA KPT-CAP - Muhyiddin. Retrieved from: https://www.bharian.com.my/berita/nasional/2020/09/736136/graduan-perlu-daftarsegera-penjana-kpt-cap-muhyiddin.

Berita Harian. (2020h). One-off RM200 bantu kesukaran pelajar ketika ini. Retrieved from: https://www.bharian.com.my/berita/nasional/2020/03/670101/one-rm200-bantukesukaran-pelajar-ketika-ini

Berita Harian. (2020i). RM72 juta tampung pengurangan yuran pengajian kerana COVID-19. Retrieved from: https://www.bharian.com.my/berita/nasional/2020/08/722368/rm72juta-tampung-pengurangan-yuran-pengajian-kerana-covid-19.

Berita Harian. (2020j). COVID-19: 74,530 pelajar terima bantuan makanan. Retrieved from: https://www.bharian.com.my/berita/nasional/2020/03/668329/covid-19-74530pelajar-terima-bantuan-makanan.

Berita Harian. (2020k). Soalan lazim pergerakan pulang pelajar IPT. Retrieved from: https://www.bharian.com.my/berita/nasional/2020/04/681922/soalan-lazimpergerakan-pulang-pelajar-ipt

Berita Harian. (20201). COVID-19 ubah pengajaran dan pembelajaran dari rumah. Retrieved from: https://www.bharian.com.my/rencana/komentar/2020/07/710464/covid-19ubah-pengajaran-dan-pembelajaran-dari-rumah

Bernama. (2020). Dana bantuan RM200 untuk pelajar telah disalur ke IPT. Retrieved from: https://www.bernama.com/bm/am/news_covid-19.php?id=1843963.

Edubestari. (2020) Penerbangan Khas Kementerian Pendidikan Tinggi untuk Mahasiswa. Retrieved from: https://edubestari.com/penerbangan-khas-kpt/.

Hamat, M., Mahlan, S. B., \& Ch'ng, P. E. (2020). Adaptasi Pengajaran dan Pembelajaran Secara Maya Dalam Kebiasaan Baharu Semasa Pandemik Covid-19. SIG: eLearning@CS: 23-30.

Hashim, N., Chang, P. K., \& Abd. Rahman, M. P. (2016). Stops: Mengungkai Isu Kebolehpasaran Graduan di Malaysia. Malaysian Journal of Communication, 32 (2): 139-164.

Hmetro. (2021a). Tangguh lagi bayaran balik pinjaman PTPTN. Retrieved from: https://www.hmetro.com.my/mutakhir/2021/01/659052/tangguh-lagi-bayaran-balikpinjaman-ptptn.

Hmetro. (2021b). Kebolehpasaran graduan perlukan komitmen banyak pihak. Retrieved from:https://www.hmetro.com.my/mutakhir/2021/08/737324/kebolehpasarangraduan-perlukan-komitmen-banyak-pihak.

Hmetro. (2020). Kerjasama Tingkat Kebolehpasaran Graduan Bumiputera. Retrieved from: https://www.hmetro.com.my/mutakhir/2020/11/643201/kerjasama-tingkat kebolehpasaran-graduan-bumiputera. 


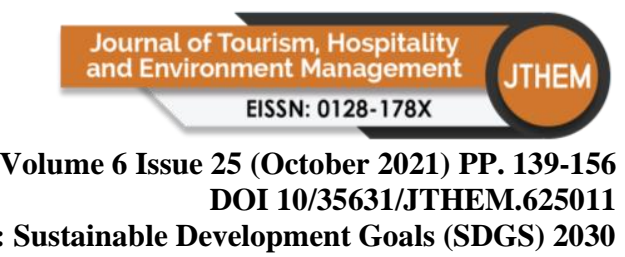

Maslan, M., \& Mohd Nor, M. Y. (2020). Kebolehlaksanaan Pentaksiran Bilik Darjah (PBD) Secara Atas Talian Sepanjang Perintah Kawalan Pergerakan (PKP) Di Daerah Sentul, Kuala Lumpur. Prosiding Seminar Nasional FIP: 213-218.

Mohd Shah, M. K., Othman, I. W., Yusoff, M. S., Ationg, R., Abu Bakar, A. L., Esa, M. S., \& Abang Muis, A. M. R. (2021). Memimpin Minat Penyertaan Generasi Muda Dalam Memperluas Peluang Pekerjaan: Seleksi Isu-Isu Sektor Industri Pembinaan Dan Pembangunan Infrastruktur. Journal of Islamic, Social, Economics and Development (JISED), 6(38), 167-187.

Mohd Nasir, N., \& Mansor, M. (2021). Cabaran Guru dalam Melaksanakan Pengajaran dan Pembelajaran di Rumah (PDPR): Suatu Pemerhatian Awal. Malaysian Journal of Social Sciences and Humanities, 6, (7): 416-421.

MOHE. (2021a). Kadar kebolehpasaran graduan rekod 84.4 peratus bagi tahun 2020. Retrieved from: https://www.mohe.gov.my/en/broadcast/media-coverage/kadar-kebolehpasarangraduan-rekod-84-4-peratus-bagi-tahun-2020.

MOHE. (2021b). Program Kebolehpasaran Graduan Industri 4.0: Kolaborasi Bersama Kementerian Pengajian Tinggi Dan Malaysia Technology Development Corporation. Retrieved from: https://www.mohe.gov.my/hebahan/kenyataan-media/programkebolehpasaran-graduan-industri-4-0-kolaborasi-bersama-kementerian-pengajiantinggi-dan-malaysia-technology-development-corporation.

MOHE. (2021c). Inisiatif Rumah Siswa Memperkasa Pengurusan Pelajar Luar Kampus. Retrieved from: https://mohe.gov.my/hebahan/kenyataan-media/inisiatif-rumahsiswa-memperkasa-pengurusan-pelajar-luar-kampus?highlight=WzIwXQ==

MOHE. (2020a). PENJANA KPT-CAP: Peruntukan RM100 Juta Bagi Menangani Isu Kebolehpasaran Graduan. Retrieved from: https://www.mohe.gov.my/hebahan/kenyataan-media/penjana-kpt-cap-peruntukanrm100-juta-bagi-menangani-isu-kebolehpasaran-graduan?highlight=WyJrcHQiXQ==

MOHE. (2020b). Teks Ucapan Majlis Menandatangani Memorandum Persefahaman Antara Kementerian Pengajian Tinggi (Kpt) Dengan Perbadanan Usahawan Nasional Berhad (Punb).

Retrieved from: https://www.mohe.gov.my/index.php?option=com_content $\&$ view=article \&id=160\&It emid $=1082$

Norhana Ahad, M. F. (2020). Analisis Faktor Tekanan yang Mempengaruhi Pelajar Kolej Komuniti Negeri Johor Ketika Perintah Kawalan Pergerakan. Jurnal Dunia Pendidikan, 150-172.

Noordin, N. H., Hashim, N., \& Abd Latib, N. (2020). Cabaran Pensyarah Kolej Komuniti Dalam Melaksanakan Proses Pengajaran dan Pembelajaran Dalam Talian. $e$ Proceedings of the Green Technology \& Engineering 2020 Virtual Conference: 193202.

Othman, I. W., Esa, M. S., Ationg, R., \& Muda, N. (2021). Relevansi Akta Pendidikan 1996 Memacu Visibiliti dan Memartabat Bahasa Melayu Sebagai Bahasa Ilmu dalam Sektor Pendidikan Negara. International Journal of Education, Psychology and Counseling, 6 (41), 137-159.

Othman, I. W., Yusoff, M. S., Mohd Shah, M. K., Esa, M. S., Ationg, R., Ibrahim, M. A., \& Raymond Majumah, A. S. A. (2021). Maslahat Literasi Pendidikan Politik Simbiosis Golongan Belia dalam Mendepani Perubahan Lanskap Kepimpinan Negara. Journal of Islamic, Social, Economics and Development, 6(38): 82 -104. 


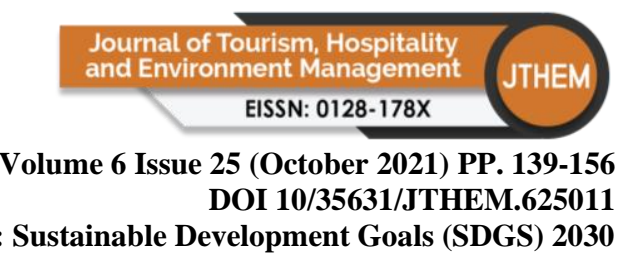

Othman, I. W., Yusoff, M. S., Mohd Shah, M. K., Mokhtar, S., Abang Muis, A. M. R., Marinsah, S. A., \& Marzuki, M. (2021). Signifikasi Keunikan Diversiti Budaya Masyarakat Majmuk Disulami Keharmonian, Disantuni Perpaduan Sebagai Nilai Tambah Kepercayaan Keluarga dan Pemangkin Diaspora Pelajar Antarabangsa Melanjutkan Pengajian Ke Malaysia. International Journal of Education, Psychology and Counseling, 6(39), 01-28.

Othman, I. W., Esa, M. S., Ationg, R., Ibrahim, M. A., Lukin, S. A., \& Abdul Hamid, J. (2021). Visibiliti Integrasi Sistem Infrastruktur dan Kesalinghubungan Universiti dalam Konteks Menjana Kelestarian Persekitaran Pembelajaran Kondusif Kampus Bertaraf Antarabangsa. International Journal of Law, Government and Communication, 6(23), 23-41.

Othman, I. W., Mohd Shah, M. K., Yusoff, M. S., Esa, M. S., Ationg, R., Ramlie, H., \& Abdul Rahman, M. H. (2021). Elemen Transformatif dan Akulturasi Diri dari Pengalaman Tahun Pertama Pengajian di Universiti Awam Malaysia sebagai Wasilah Prestasi Pencapaian Akademik Pelajar Antarabangsa. International Journal of Education, Psychology and Counseling, 6(39), 29-55.

Othman, I. W., Ibrahim, M. A., Esa, M. S., Ationg, R., Mokhtar, S., Mohd Tamring, B. A., \& Sharif Adam, S. D. (2021). Literasi Undang-Undang Sinonim Kemandirian Jati Diri Mahasiswa dalam Lanskap Politik Kampus: Pemacu Generasi Muda Berjiwa Besar dan Tinggi Karisma Kepimpinan. International Journal of Law, Government and Communication, 6(23), 215-242.

Othman, I. W., Ationg, R., Esa, M. S., Hajimin, M. N. H. H., \& Abang Muis, A. M. R. (2021). Signifikasi Prinsip Hidup Merujuk Keterkaitan Agama, Budaya, Amalan Kepercayaan dan Wawasan Dunia Secara Keseluruhan (Worldview): Motif Ekspatriasi Ahli Akademik Islam dalam Membina Kerjaya di Malaysia. International Journal of Law, Government and Communication, 6(23), 85-103.

Othman, I. W., Yusoff, M. S., Esa, M. S., Ibrahim, M. A., Mohd Tamring, B. A., \& Mohd Shah, M. K. (2020). Relevansi Pembangunan Kendiri dalam Pemantapan Kerjaya Ahli Akademik Ekspatriat di Universiti Awam Malaysia. International Journal of Education, Psychology and Counselling, 5 (37): 253-269.

Othman, I. W., Yusoff, M. S., Marinsah, S. A., Mokhtar, S., Ramlie, H. A., \& Mohd Shah, M. K. (2020). Strategi Akulturasi dan Hasil Pembudayaan Berbeza dalam Kalangan Pelajar Antarabangsa Universiti Awam Malaysia, Journal of Tourism, Hospitality and Environment Management, 5 (21): 123-142.

Othman, I. W., Yusoff, M. S., Lukin, S. A., Ationg, R., Abang Muis, A. M. R., Mohd Shah, M. K. (2020). Adaptasi Kemandirian dan Kelestarian Prestasi Akademik Pelajar Antarabangsa Universiti Awam Malaysia. International Journal of Law, Government and Communication. 5 (21): 138-159.

Othman, I. W., Jupiter, H., \& Mohd Suki, N. (2019). Factors Affecting the Tendency of International Students to Pursue Study in Universiti Malaysia Sabah. International Journal of Psychosocial Rehabilitation, Vol. 23 (2):185-200.

Othman, I.W., Yusoff, M.S., Abdul Hamid, A.B., Awang, H., \& Jupiter, H. (2018). Implikasi Ekspatriasi Pelajar Antarabangsa ke atas Peningkatan Aspek Kualiti Hidup di Negara Tuan Rumah. International Journal of Law, Government and Communication, 3(7), 4052.

Othman, I. W., Awang, H., Hamid, A. B. A., Yusoff, M. S., \& Jupiter, H. (2018). The Study of First Year International Students' Expatriate Experiences in University of Malaysia Sabah. Journal of Tourism, Hospitality and Environment Management, 3(8):34-43. 


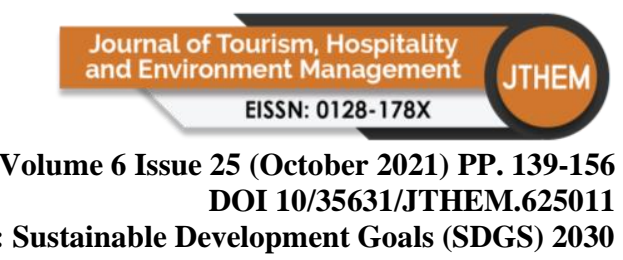

Othman, I. W., Jupiter, H., Abdul Hamid, A. B., Yusoff, M. S., \& Awang, H. (2018). Faktor Sosial yang Mempengaruhi Keputusan Pelajar Antarabangsa dalam Pemilihan Destinasi Pengajian: Kajian Kes di Universiti Malaysia Sabah (UMS). Journal of Islamic, Social, Economics and Development, 3(8):87-97.

Othman, I. W., Jupiter, H., Awang, H., \& Yusoff, M. S. (2017). Faktor Ekonomi dalam Mempengaruhi Keputusan Pemilihan Destinasi Pengajian Pelajar Antarabangsa di Luar Negara. Journal of Islamic, Social, Economics and Development, 2(3):01-08.

Othman, N. Z., \& Hussin, S. F. (2019). Faktor-Faktor yang Mempengaruhi Tahap Kebolehpasaran Graduan Mengikut Bidang Pengajian di Politeknik Mersing. E-Jurnal Liga Ilmu Serantau 2019: Malaysia Indonesia (LIS 2019): 277-289.

Sinar Harian. (2020a). KPT peruntuk RM24 juta Bantuan Pelan Data untuk pelajar IPT B40. Retrieved from: https://www.sinarharian.com.my/article/107774/BERITA/Nasional/KPT-peruntukRM24-juta-Bantuan-Pelan-Data-untuk-pelajar-IPT-B40.

Sinar Harian. (2020b). KPT tubuh portfolio khas urus pelajar luar kampus. Retrieved from: https://www.sinarharian.com.my/article/116664/BERITA/Nasional/KPT-tubuhportfolio-khas-urus-pelajar-luar-kampus

Syed Sahil, S. A., \& Hassan, H. (2018). Ke Arah Kebolehpasaran Graduan: Pertalian Antara Pendekatan Pembelajaran dengan Kemahiran Insaniah dalam Kalangan Pelajar IPT Berteraskan Islam. Jurnal Pendidikan Malaysia, 43(2): 81-90.

UTM. (2018). Congratulation Arif Tukiman and RunCloud Team. Retrieved from: https://xcite.utm.my/congratulation-arif-tukiman-and-runcloud-team/

Utusan. (2020). Covid-19: Pendaftaran kemasukan pelajar ke IPT ditangguh. Retrieved from: https://www.utusan.com.my/gaya/kampus/2020/10/kemasukan-pelajar-ke-iptditangguh/

Pokhrel, S., \& Chhetri, R. (2021). A Literature Review on Impact of COVID-19 Pandemic on Teaching and Learning. Higher Education for the Future, 8(1):133-141,

Wan Ya Shin (2020). Pendidikan Sepanjang Krisis COVID-19, Institusi Demokrasi dan Hal Ehwal Ekonomi (IDEAS).

Yusoff, M. S., Othman, I. W., Mohd Shah, M. K., Esa, M. S., Abang Muis, A. M. R., Marinsah, S. A., \& Ramlie, H. (2021). Falsafah Pelan Strategik Universiti Awam Malaysia Melalui Pengalaman Ahli Akademik Ekspatriat dalam Mengorak Reputasi Universiti Sebagai Hab Kecemerlangan Akademik di Persada Antarabangsa. International Journal of Education, Psychology and Counseling, 6(39), 56-73.

Yusoff, M. S., Othman, I. W., Jupiter, H., \& Mokhtar, S. (2021). Penguasaan Bahasa Ibunda Sebagai Medium Komunikasi Mahasiswa Institusi Pengajian Tinggi Malaysia: Suatu Penelitian Cakna Bahasa Negara Berbilang Kaum. International Journal of Education, Psychology and Counseling, 6 (41), 38-54.

Yahaya, M., \& Adnan, W. H. (2021). Cabaran Pelajar Melalui Kaedah Pembelajaran Atas Talian: Kajian Institusi Pengajian Tinggi Awam Malaysia. Journal of Media and Information Warfare, 14(1): 11-20. 